\title{
Energy use in informal food enterprises: A gender perspective
}

\author{
Margaret N. Matinga ${ }^{1 *}$, Nthabiseng Mohlakoana², Jiska de Groot ${ }^{3}$, \\ Abigail Knox ${ }^{4}$, Hans Bressers ${ }^{2}$ \\ 1 Dúmanai Energy, P.O. Box 476, Zomba, Malawi. \\ 2 Department of Governance and Technology for Sustainable Development, University of Twente, The \\ Netherlands. \\ 3 Energy Research Centre, University of Cape Town, South Africa. \\ 4 Department of Sociology, University of Cape Town, South Africa.
}

\begin{abstract}
The informal sector provides economic opportunities to the poor, and in sub-Saharan African countries it is dominated by women. Energy is a key input into the food sector enterprises. A study was carried out to review academic and non-academic literature on the use and gender impacts of modern energy in informal food enterprises. The review established that few studies have addressed energy for the informal food sector from a gender perspective. Although these few are qualitative in nature, they tend to lack in-depth analysis of gender and of the cause-and-effect linkages between modern energy use in the informal sector and the gendered goals of women and men. Moreover, a lack of understanding of gender from a relational perspective focusing on both women and men impeded conclusions on empowerment in terms of whether increased access to modern energy in the informal food sector contributes to closing the gender gap. This paper makes three key recommendations. First, scholars need to address the gaps and take a relational approach, so that studies are not just about women but also about the power relations
\end{abstract}

between various groups of women and men. Secondly, policy needs to recognise that biomass is sometimes desired not just as an energy source but also for the flavour it imparts to food. Lastly, policy should be informed by the needs of informal enterprise owners and their customers, not by the general discourse in the energy sector that assumes that increased uptake of modern energy services makes positive contributions to enterprises.

Keywords: informal food sector, gender, energy use

Highlights:

- There is a lack of evidence on the role of energy in the informal food sector from a gender perspective.

- Biomass is prevalent in the informal food sector due to the sector's specific energy needs and to socio-cultural practices.

- There is a need for studies on gender and energy from a relational perspective in relation to energy and entrepreneurship.

Journal of Energy in Southern Africa 29(3): 1-9

DOI: http://dx.doi.org/10.17159/2413-3051/2018/v29i3a4357

Published by the Energy Research Centre, University of Cape Town ISSN: 2413-3051 http://journals.assaf.org.za/jesa

Sponsored by the Department of Science and Technology

\footnotetext{
* Corresponding author: Email: mmat_001@yahoo.com
} 


\section{Introduction}

This study presents the results of a literature review on the use of modern energy services in informal food enterprise and related gender impacts. The review established that, despite energy being a key input for food preparation and process enterprises, few studies have investigated the informal food sector taking a gender approach.

Over the last two decades, the informal economic sector outpaced the formal economy in creating economic opportunities for women and men in developing countries, particularly in SubSaharan Africa, where employment opportunities in the formal sector are scarce, especially in areas where literacy levels are low. The informal economy had an advantage over the formal because of low entry barriers - including low capital requirements and reduced business costs because many informal businesses do not pay tax or have costs such as holiday and maternity cover and insurance. The ILO (2015a) reports that non-agricultural employment in the informal economy represents 66 per cent of total employment in Sub-Saharan Africa and 52 per cent in North Africa.

As in all aspects of socio-economic life, there is a gender divide in the informal sector. For example, 'in Sub-Saharan Africa, 74 per cent of women's employment (non-agricultural) is informal, in contrast with 61 per cent for men' (ILO, 2015b:01). Women tend to be concentrated in food processing and preparation, domestic work, and health and education services. They tend to dominate these sub-sectors because they rarely have the vocational and skills training to enter other sectors, and so tend to use skills gained in their gendered roles to start enterprises (Meagher, 2010). Women's enterprises tend to be more vulnerable to economic shocks and restructuring because of their subjugated status in many developing countries. It was found, for example, that modernisation and restructuring of economies often takes away jobs traditionally done by women, such as food processing or sewing (Kemp, 1993). Similarly, in times of economic crisis, men join the informal sector in greater numbers, sometimes altering traditional gender patterns (Yasmeen, 2001).

One informal sub-sector in which women dominate is the food processing and preparation sector (Chen, 2001; Brown, 2006). Even in countries where women typically do not work outside the home for religious and cultural reasons, they have opportunities in the informal food sector by either selling their products from home or by being 'the hands behind the male face' of the business - cooking and processing food at home, while male relatives or business partners sell it in the public sphere (Etzhold, 2015). On the other hand, there is an increase in men's participation in sectors that have previously been dominated by women, including the informal food sector (Overå, 2007). These dynamics call for critical questions relating to gender and economic opportunities, especially in urban areas.

The study set out to identify and examine the empirical literature on gender and modern energy use in the informal food sector, to explore the gender, energy and informal food sector nexus. This area of enquiry is important because, despite expectations that access to energy for productive use empowers women by enabling them to generate income, women in developing countries face a range of barriers when establishing and operating enterprises, including access to energy (de Groot et al., 2017).

A brief account of methodology in Section 2 is followed in Sections 3 and 4 by the identification of key gender dynamics applicable to modern energy use in the informal food sector. Section 5 examines the evidence on the positive and negative impacts of modern energy services on women's and men's informal food enterprises. Section 6 discusses the advantages and limitations of modern energy services in the informal food sector, based on the emerging evidence. A concluding section highlights the key gaps in the literature and draws out implications for current and future developments in research and policy making.

\section{Methodology}

A review of empirical academic and non-academic literature such as project reports, both published and unpublished, was undertaken. The selection was based on three themes: the informal food sector, gender, and energy for productive uses. A range of search engines was used to find material, including Web of Science, African Journals Online and Google Scholar; with further papers found by the snowball technique. Inclusion criteria were that studies focused on urban areas, outlined effects of modern energy use on businesses or business owners, used sex-disaggregated data, and concerned informal food preparation and processing.

\section{Importance of the informal food sector for livelihoods}

Initially understood as a temporary mechanism for coping with economic shocks, the informal sector in general appears to be resilient and has over the years expanded rather than shrunk as expected (Chen et al, 2002; ILO, 2002; Bigsten et al., 2004). The informal food sector is no different. Even though academic and policy categorisations would classify many of the informal food sector enterprises as survivalist in nature, some informal food sector enterprises do grow and are medium-to-long-term livelihood strategies. Survivalist enterprises tend to be regarded as informal in nature and found mainly in poor areas, operating on roadsides and without 
financial security to sustain the businesses, which are mainly operated by women (Berner et al., 2012). Growth of informal enterprises could entail earning incomes above the poverty line, expanding the customer base or product or service range, and increasing profitability or revenue. A snapshot study of women in the informal food sector in Accra showed that women participated in street food vendors as a long-term enterprise, actively trading for 7-20 years and growing their businesses from feeding a few customers to selling several meals a day and even catering for events (Matinga, 2015). In Rwanda, Senegal and South Africa, female-owned enterprises in the sector have been in existence longer than those owned by men; for example, up to $89 \%$ (41 out of 46 ) of enterprises that are more than ten years old belonged to women. Furthermore, $75 \%$ of enterprises that were five to ten years old were owned by women (Bressers et al., 2016).

The informal food sector, especially street-vended food on the consumer side, changed from the occasional meal to an important source of affordable nutrition, particularly for the urban poor across the globe as shown by Chukuezi (2010) in Nigeria; Mosupye and von Holy (1999) in South Africa; and Muzaffar et al., (2009) in Bangladesh among others. The studies by FAO in Ghana and in Thailand show that the informal food sector often provide one to two meals a day for office-workers, travellers, school-children and households (Fellows and Hilmi, 2011; FAO, 2012). It is estimated that, globally, over 2.5 billion people eat street food every day (FAO, 2012). Among buyers of street food in Bangkok, Thailand, the second-most-cited reason for purchasing street food (after proximity to home) was because it is cheap. In Bamako, Mali, street food constitutes 19-27\% of the household food budget (Ag Bendech et al., 2013). In Lusaka, Zambia, food vendors sell about 81 million meals per annum (Graffham et al., 2005).

There is less documentation of informal food processing, especially in the urban environment, while there is an emerging interest in street food. A brief period of interest in informal food processing was observed in the 1980s, when debates on women's drudgery and issues of appropriate technologies and mechanisation were common (Tinker, 1981; Carr, 1981). Many of these discussions pertained, however, to domestic production in rural areas and ignored women as economic agents in food processing. Both food vending and food processing subsectors experience low levels of access to modern technologies, modern energy services and finances, and have little social and legal protection (Horn, 2009; de Groot, 2017; ILO, 2015).

Studies on the impact of the sector from a gender perspective are few, despite the contributions of the informal food sector to livelihoods and its importance as a livelihood strategy for women.
Some of biggest gaps in knowledge are with respect to the impact of energy, whether modern or traditional, on these informal businesses, as well as to women's role and positions in them. Common among these characteristics is that women with low levels of literacy tend to dominate street food vending. A 2003 census of street vendors in Harare, Zimbabwe, for example, showed that about 8631 people were involved, of whom $81 \%$ were women (Graffham et al., 2005). In Bahia, Brazil, $55.9 \%$ of 247 food vendors interviewed were female with low levels of education (49\% had elementary education or lower) (da Silva et al., 2014). A study of 334 street vendors in Accra, Ghana, showed the sector employing more than 60000 women and men, with $94 \%$ of food vendors being women with minimal or no education (NRI, 2015). These findings were later corroborated by studies in Ghana and elsewhere in Africa where the majority of vendors, including street food vendors, were illiterate or semiliterate women (Osei-Boateng \& Amaratwum, 2011). This important aspect of the informal food sector - that it presents economic opportunities for women with few prospects - is dealt with in Section 4.

\section{Gender dynamics in the informal food sector}

In processing cassava, grating, dewatering and milling operations are dominated by men, while peeling, washing, drying and frying operations are dominated by women (Davies et al., 2008). In West African diary processing, men are involved in livestock care, but it is women that do the milking and dairy processing, although this is also governed by complex arrangements based on ethnicity, religion, and economic status, among other variables (Waters-Bayer, 1985). In Nigeria and Senegal, for example, the Fulani women process, market and make decisions over milk, including how much is consumed and sold, and do sell it directly themselves, as do women in Somalia (Dietz et al., 2001). Wealthy Fulani women and strict Muslim women, however, often use intermediary women (Corniaux, 2003; Waters-Bayer, 1985) such that critical power relations are between women of different status as much as between women and men.

\section{Evidence of gendered energy use and impacts in the informal food sector 5.1 Gendered patterns of energy use in food enterprises}

One study highlighted the gender and energy dynamics in the food sector as a whole, including both formal and informal sectors (Onyeneho and Hedberg, 2013). This study was on food safety in restaurants in Imo State, Nigeria, where restaurants were classified into four categories: Class A being major hotels, Class B school cafeterias, Class $\mathrm{C}$ reg- 
ular/fast food restaurants, and Class D 'bukas' or 'bukaterias' - consisting of food kiosks, roadside food sellers and mobile food sellers or food hawkers (collectively termed street food vendors in the present study). It was found that all the bukaterias were owned by females with only primary school education and that none of them had refrigerators, while all other categories had some refrigerators. The reasons for bukaterias not having these facilities were not explored, but could be attributed to lack of capital, lack of access to modern energy, or lack of security of location, since bukaterias are often harassed and moved by local authorities.

In India, productive uses of energy were explored, and it was found that the uptake of both electricity and liquefied petroleum gas (LPG) among entrepreneurs, many of whom ran restaurants and tea shops, was not significantly different for males and females (Kooijman-van Dijk, 2008). Men's enterprises, however, had better opportunity to improve access to modern energy services because they could occupy central locations. Men could also increase access to customers, while women in most Indian communities faced barriers in trading outside the family home. The DfID-funded study on energy and urban livelihoods in Plataforma and Canabrava communities, Bahia, Brazil, divided food-producing and -selling businesses into three categories: those that used one to two LPG cylinders, those that used more than two, and those that used none (Winrock, 2005). The majority ( $89 \%$ or 25 out of 28 ) of these businesses were women-owned. It was found that $72 \%$ of women entrepreneurs who sold food and beverages used one to two cylinders per month. Among the food businesses owned by men, 33\% used more than two cylinders a month compared with only $20 \%$ of women's businesses (Winrock, 2005). The proportion of men likely to use no LPG was $67 \%$, compared with $8 \%$ for women. The study does not offer reasons for this discrepancy; one reason could be that men are less likely than women to engage in food enterprises requiring thermal energy, but the study is unclear as to what food the different enterprises prepared. Bressers et al. (2016) showed that $78 \%$ (32 out of 41 ) of males with enterprises in the informal food sector in Rwanda, Senegal and South Africa used traditional sources of energy such as wood and charcoal, while $62 \%$ (86 out of 138) of females also used traditional energy sources.

\subsection{Use and impacts of different energy types in cooked food vending}

Few studies have attempted to examine the impacts of modern energy services on women's and men's informal food enterprises in any depth, and all were qualitative in nature. In a study of the impacts of LPG on women's livelihoods in Accra, Ghana, female respondents reported that LPG reduces drudgery by eliminating tedious processes of lighting and tending to traditional open fires. Furthermore, the clean-burning LPG reduced the time spent on scrubbing pots, leaving business owners more time to spend with their families (Matinga, 2015). The LPG-fuelled ovens were also said to improve time management compared with (improved) wood-ovens because they come to temperature instantly, as opposed to wood ovens where one has to wait longer for the oven to heat. The LPG was, in general, seen as being useful in improving product quality because of better temperature control, thus improving the ability to respond speedily to customer needs. Kooijman-van Dijk (2008) found that in India one female owner of a teashop valued the fact that using LPG reduced the destruction of forests and lessened the need for helpers in the kitchen, the latter factor suggesting that LPG reduces drudgery. Women were more likely than men to value the fact that LPG kept kitchen walls and dishes clean; male owners of teashops cited only the values of comfort of use and providing fast service as the motivation for using LPG. A study in the Philippines cited clean burning and enabling fast service as the benefits of using LPG in carinderias (Approtech-Asia, 2005).

A study by Tedd et al. (2003) focused on the promotion of improved cookstoves for street food vendors in Dhaka, Senegal. Impacts of these cookstoves were assessed among 100 enterprises, where $95 \%$ of the vendors were female, of whom $27 \%$ were food processors. All cookstove users reported experiencing increased savings and could use the savings for purchasing other items. A total of 26 $(97 \%)$ reported experiencing increases in stock as well as improvement in lifestyle, and $53 \%$ of these entrepreneurs also reported a reduction in medical costs. The study, however, made no in-depth analysis of the pathways to these benefits but attributed them to the improved efficiency of the cookstoves. About 14 respondents used improved commercial cookstoves and ten of these reported increases of $31 \%$ or more in profit margins, while the other four experienced improved profit margins of $16-30 \%$. All users also felt that they required less time to cook on improved cookstoves than on traditional stoves. It is noted that the $95 \%$ female component of this study was part of the project and not reflective of the actual situation. In the actual context of this Dhaka study, men dominated street food vending because, while women were involved in preparing the food, it was often men that were present at the point of sale (Tedd et al., 2003), probably because of religious and cultural constraints; but the research wanted to specifically capture women's views.

Of the four studies cited above, examining use and impacts of different energy types, only Kooijman-van Dijk (2008) compared women's and men's food enterprises, She found no difference in 
the impacts that women and men's businesses experienced (Kooijman-van Dijk, 2008). The results from Matinga (2015) were based on intentionally interviewing women only; and those of Approtech Asia (2005) in the Philippines were also based on focus group discussions with women only. The study by Tedd et al. (2003) included data from women and men but did not provide a breakdown on differences in benefits; given the gender divide in roles, however, it is likely that benefits such as time-saving and improved health as a result of improved stove utilisation accrued to women, and increased revenue to men. The study by Bressers et al. (2016) The present survey asked enterprises if they were using energy sources that reduced their workload. Out of 178 respondents, $48 \%$ indicated that they did not use energy sources that could reduce the time spent on difficult tasks and $38 \%$ saw no (energy) alternatives to the ones they were using. Only $11 \%$ of the female respondents indicated that they used sources that reduced their workload, while only $3 \%$ of males indicated the same.

\subsection{Use and impacts of energy in food processing}

Studies on gender, energy, and food processing (as opposed to preparation) are generally lacking, but the Mali multifunctional platforms - a government managed, multilaterally sponsored energy programme, which powers food processing as well as water pumping, battery charging, welding and other services does provide some insights (Sovacool et al., 2013). The platforms provide women's groups with diesel-powered engines that allow them to process grains, nuts, cereals and other food products (Sovacool et al., 2013). In the assessment of its impacts, women reported that their incomes improved; the increase was estimated to be as much as USD 44 per year. Increase in incomes was attributed to better productivity and better product quality because of powered processing, which enabled women to charge higher prices. Changing from manual to powered food processing also reduced drudgery and time spent on the process. The time saved was used to cook for family, whereas previously, meals for men and children were skipped because of women's time pressures; this had the potential to improve family nutrition. In addition, women had more time for leisure and entertainment. Men also saved time and used it to start businesses and benefited from women's saved time because they had timely meals. The study by Sovacool et al. does not elaborate on how men saved time, but the platforms powered other activities in addition to food processing, which could account for it.

At a very basic level, energy is critical to food processing, as it allows transformation of foodstuffs into desired forms, e.g., through cooking, preserva- tion through drying in the sun or smoking and sterilisation (including pasteurisation). Conducting these processes without appropriate and affordable forms of modern energy is arduous and therefore often left to women because their time is valued less. The absence of refrigeration, sterilisation and temperature control means food can go putrid, increasing chances of food-poisoning, to the detriment of both customers and businesses. Reduced drudgery and improved food safety means that modern energy can contribute to the practical needs of women and men. However, while modern energy use can have several advantages over traditional forms of energy for informal food businesses, it is not without its limitations, as illustrated in Section 5.4 .

\subsection{Limitations of modern energy services in the informal food sector}

Studies that focus on the negative impacts or limitations that might result from switching to modern energy use are scarce. Other literature on energy transitions, however, reveals potential negative impacts that could result from an unreliable supply of modern energy or from consumer preferences associated with the flavour of food cooked on open fires or charcoal. The DfID-funded study on energy, gender and urban livelihoods in Nigeria examined energy use in fish-smoking enterprises, a sector dominated by women (Maduka, 2006). Fuels used were firewood, sawdust and kerosene. Price hikes in petrol affected businesses because the firewood was transported by car into urban areas. It was also found that the women, despite acknowledging disadvantages of fuelwood such as eye problems from smoke, were reluctant to switch to LPG because its smokeless operation was perceived to affect the characteristic flavour of smoked fish, leading to women fearing a loss of customers (Maduka, 2006). The women's priority was not modern energy but (micro) credit.

Matinga (2015) and Approtech-Asia (2005) referred to modern energy supply issues and its impact on the informal food sectors in Ghana and the Philippines, respectively. At the time of both studies, supply reliability of modern energy (LPG in the case of Ghana and LPG and electricity in the case of the Philippines) was not considered problematic, although it had been so in the past. In both cases, however, the costs of LPG and electricity were said to be a form of constraint on businesses. In the Philippines study, a coping mechanism demonstrated by only one of the eleven eateries studied was to use kerosene and wood as complementary fuels. This appeared to be in line with the Ghana case where, after an increase in LPG costs, enterprises did not switch fuels. In both studies, most entrepreneurs did not appear to have changed fuels because of increased cost. A mechanism used 
for coping with high energy costs in the case of the Philippines was reducing staff numbers. Choosing to do this rather than regress to traditional fuels signifies the high value placed on modern energy fuels. It is likely that, in the case of food enterprises in these two countries, the advantages of using LPG were highly valued and enterprises would rather incorporate energy price changes into food prices as a coping mechanism than regress to traditional fuels and lose the benefits of modern energy. In neither study was there any assessment of gender differences in the impacts on informal food businesses or coping mechanisms.

While there are no specific explorations of potential limitations related to food flavour, studies from household energy use have shown that the flavour imparted by firewood or charcoal can affect a household's decisions about changing to modern energy for cooking. A question to be asked in the informal sector, then, is whether and in what informal food enterprises a transition to modern energy services would result in customer loss because of changes in food flavours. Matinga (2015) observed that informal food vendors in Ghana used charcoal particularly for traditional foods - this could be as a way of both coping with the costs of LPG and of maintaining expected flavours. In the Philippines study, one eatery used charcoal not because of LPG or other modern fuel constraints but because it was the preferred fuel for grilling (Approtech Asia, 2005). As mentioned above, in Nigeria, women entrepreneurs feared of losing customers through switching from wood to LPG in fish-smoking (Maduka, 2006), but whether this loss materialised is not known, since the study did not compare businesses that had changed to LPG with those that used firewood.

The fact that the introduction of modern fuels such as LPG could reduce necessary labour to the extent of allowing a reduction in the workforce (Kooijman-van Dijk, 2008) is an advantage to business-owners, though obviously a disadvantage for those who lose their employment. Such loss of employment is likely to impact women more than men because it is women who are often employed in this sector.

\section{Discussion}

The studies reviewed in this paper expose some areas of interest in terms of considerations for academic and policy inquiry. Beyond showing the importance of the informal food sector as a source of income (mostly for women but also for men), it was found that, for the informal food sector, differentials of energy access between women- and menowned businesses were unclear, but that sex was an unlikely factor in whether an informal food business has modern energy access. Studies, conducted in Brazil and India (Winrock, 2005; Kooijman-van
Dijk, 2008) and in Sub Saharan Africa (Bressers et al., 2016), examined the sex of the business owner and modern energy use, and found that sex was not a factor in determining the use of modern energy in the informal food sector. The study in India, however, found that improving modern energy use was limited for women because of cultural constraints, which also limited their access to customers. It was also found that the location of the business might be a more significant factor than the sex of the owner in determining access to modern energy services. Men in the India study had better business locations and these have better access to modern energy such as LPG and electricity. The Brazil study (Winrock, 2005) noted women's strong wish use LPG. Nonetheless, men's informal food businesses were likely to use more LPG than women's, with the study showing women likely to use one to two cylinders a month, while the proportion of male-owned businesses using more than two cylinders a month was marginally more than that for female-owned food businesses. The reasons for limited use of LPG in women's businesses in the Brazil study were less clear but likely to be economic, and related to the location and the size of the businesses. The three studies showed further that, while access to modern energy might be the same for female- and maleowned businesses, increased use of it was more limited for women. Women's inability to increase modern energy use after initial access might be attributable to lower capital capacity, although reasons for the difference remain uncertain.

A critical gap in the studies on energy access for the informal food sector is that, despite the suggestion that location matters in access to modern energy services, the studies do not address whether location and local government and planning policies affect whether men and women access modern energy services. The studies are silent on whether and how such local government and planning policies and reforms (e.g. decentralisation policies) might affect energy access in the sector, and the gender differences of such effects. For example, would women and men risk investing in modern energy access if their businesses can be confiscated or if they can be moved to different locations on spurious grounds? What happens to energy-use patterns, including costs and other associated risks, when women and men in the informal food sector are forcibly relocated in the interest of urban planning and modernisation goals? Does local government and planning policy take into consideration modern energy access for the informal food sector? Semi-formalisation of previously informal street businesses in Rwanda, for example, might decrease police harassment and dependency on civil servants, given that business registration guarantees certain rights and provides some protection (Bressers et al. 2016). 
There is little in-depth investigation of whether impacts are different for women and men, but studies have identified several impacts that are beneficial for women. Those cited in the six studies that discussed impacts include reducing drudgery and saving time. Further, four studies show that modern energy services improve product quality and customer service, both of which are likely to improve profitability. The studies by Matinga (2015) and Tedd et al. (2003) show improvements in profitability as a direct result of using modern energy in food preparation enterprises that previously used traditional energy sources, while Kooijman-van Dijk (2008) suggests reduction in labour costs, which could in turn improve profitability. Only Kooijman shows benefits to both women and men and concludes that sexes experience the same benefits but that there were different motivations for female and male food enterprise owners opting for modern energy. While women were motivated by broader concerns such as environment (deforestation), customer comfort and clean kitchen walls and dishes, men cited only comfort of use and providing fast service as the motivation for using LPG. . The lack of studies that compare impacts on women and men, and their different experiences, is a critical gap. Further studies are needed to inform how best to promote modern energy services to women and men in the informal food sector by, among other things, highlighting if and how women and men in the sector differ in their energy needs, access to opportunities, and the causes for these differences.

Gender roles in the domestic spheres where women are the main cooks and men are seen as economic heads (despite women also earning incomes) are reflected in informal businesses where women are largely responsible for cooking while, in some cases, men are the ones that sell the products (Kooijman-van Dijk, 2008; Tedd et al., 2003). On the other hand, household members provided labour for the businesses as shown by Matinga (2015). A question then arises as to whether energy policies for household energy access and use, such as subsidy policies for poor families, should go beyond household consumption to include energy for informal enterprises.

Another gap in the literature is that of access to capital and energy in the informal food sector. Although not specifying whether the businesses are formal or informal, but including rural and urban enterprises, and not an energy study per se, at least one study by USAID showed that food processing businesses were least likely to be served by formal financing institutions and constituted only $5 \%$ of customers (whether new or repeat) for the banks examined in the study (Agabin and Gusto, 2006: 14). Carinderias or Filipino food kiosks were $8 \%$ of repeat customers and $9 \%$ of new ones, although their average first loan amounts were the highest.
The Approtech Asia (2005) study points to problematic access to credit for carinderias and canteens, arguing that most of these carinderias access informal credit at an interest rate of $20 \%$ per week (although it does not go into detail). Given that women's access to capital is problematic and that modern energy services policy has taken on a neoliberal, market-driven approach, how does this affect access to modern energy for women- and men-owned informal food enterprises? Would improved access to credit be necessarily used for modern energy or purchasing appliances for use with modern energy services?

A key question that is largely missing from the studies on energy and gender dynamics in the informal food sector is whether the use of modern energy in the informal sector is empowering to women. The studies considered in this paper show that timesavings and improved business outcomes suggest an improved economic position for women and hence a possibility for economic empowerment. However, the analysis across the studies shows that the concept of empowerment is not clearly elaborated. Moreover, where it is implied, the empowerment notion dealt with can be considered to be vertical: i.e. how women have moved from a previous position of disadvantage to a present better position. What is not explored is the horizontal aspect of empowerment: whether their positions have changed with respect to men's positions, leading to a narrowing of the gender gap. This appears to be a common issue in gender and empowerment studies in the energy sector and comes in part from focusing on collecting data from women only.

\section{Conclusions}

A literature review between October 2015 and February 2016 was conducted on energy in the informal food sector, focusing on gendered impacts of modern energy use. The first key finding of this literature review is that there is a dearth of literature on gender and energy within the informal sector. Secondly, the review shows that, while women dominate the informal food sector, patterns of use of different types of energy, and especially traditional and modern forms, are gendered. Third, the review shows that modern energy such as LPG can have a positive impact on businesses by improving the quality of end-product because of enhanced capacity to control temperature, improved responsiveness to customers' need for speedy service, cleanliness of environment including the ambient air quality, and time saving. Similarly, improved cookstoves improve businesses due to improved cleanliness and time saving. Such improvements can improve the profitability of women's businesses as well as working environments. Fourth, literature on food processing businesses is even less than that on cooked food. Finally, the use of modern energy 
sources for the benefit of the informal food sector is impeded by unreliable supply, leading to continued use of traditional fuels.

This literature review could contribute to closing the knowledge gap of the gender impacts of modern energy on the informal food sector. There is a lack of conceptual clarity in impacts, particularly those pertaining to empowerment, in that the few studies that address gender and energy in the informal food sector do not define what is meant by empowerment. Finally, the review of the literature, as well as data emerging from our own project on the productive uses of energy in the informal food sector, suggest that the use of biomass as an energy source will continue in the informal sector for reasons including affordability, accessibility and consumer preference. Efforts to support access to modern energy services in the informal food sector must therefore include supporting sustainable (including safe) use of biomass energy.

\section{Acknowledgement}

This review is part of the research project titled 'Productive uses of energy: The informal food sector in South Africa, Rwanda and Senegal', which was commissioned under the Gender and Energy Research Programme by the International Network on Gender and Sustainable Energy and funded by the United Kingdom's Department for International Development.

\section{References}

African Union. 2008. Study on the informal sector in Africa - Sixth ordinary session of the Labour and Social Affairs Commission of the African Union. African Union: Addis Ababa.

Ag Bendech, M., Tefft, J., Seki, R. and Nicolo, G. 2013. Street food vending in urban Ghana: Moving from an informal to formal sector. GhanaWeb. Article, 292956.

Approtech-Asia. 2005. Enabling urban poor livelihoods policy making: Understanding the role of energy services: Country report Philippines. APPROTECH: Manila.

Ayenew, Y. A., Wurzinger, M., Tegegne, A. and Zollitsch, W. 2009. Handling, processing and marketing of milk in the North western Ethiopian highlands. Livestock Research for Rural Development 21(7): Article no. 97.

Berner, E., Gomez, G. and Knorringa, P. 2012. Helping a large number of people become a little less poor: The logic of survival entrepreneurs. European Journal of Development 24: 382-396. https://doi.org/10.1057/ejdr.2011.61

Bressers, H., Mohlakoana, N., Matinga, M., de Groot, J., Batidzirai, B., Knox, A., van der Plas, R. and

Charmes, J. 2012. The informal economy worldwide: Trends and characteristics. The Journal of Applied Economic Research 6(2), 103-132. https://doi.org/10.1177/097380101200600202

Chukuezi, C. O. 2010. Entrepreneurs of the streets:
Socio-economic features of street food vending in Owerri, Nigeria. European Journal of Social Sciences 14(2), 183-188.

Codjia, G. 2000. FAO technical support for improvement within the street food sector. Pretoria: Government Printer.

Cohen, M. J. and Garrett, J. L. 2010. The food price crisis and urban food (in)security. Environment and Urbanization 22(2), 467-482. https://doi.org/10.1177/0956247810380375

Corniaux, C. 2003. La filière lait et produits laitiers dans la région de Saint-Louis. Saint-Louis, Senegal: ISRA/CIRAD-PSI

Da Silva, S. A., Cardoso, R. D. C. V., Góes, J. Â. W., Santos, J. N., Ramos, F. P., de Jesus, R. B. and da Silva, P. S. T. 2014. Street food on the coast of Salvador, Bahia, Brazil: A study from the socioeconomic and food safety perspectives. Food Control 40: $78-84$ https://doi.org/10.1016/j.foodcont.2013.11.022

Davies, R., Olatunji, M. and Burubai, W. 2008. A survey of cassava processing machinery in Oyo State. World Journal of Agricultural Sciences 4(3): 337 340.

De Groot, J., Mohlakoana, N., Knox, A. and Bressers, H. 2017. Fueling women's empowerment? An exploration of the linkages between gender, entrepreneurship and access to energy in the informal food sector. Energy Research \& Social Science 28: 86-97. https://doi.org/10.1016/j.erss.2017.04.004

Dietz, T., Abdirizak, A. N., Adano, W. R. and Zaal, F. 2001. Pastoral commercialisation: On caloric terms of trade and related issues. In M. Mohamed Salih, T. Dietz and A. G. M. Ahmed (Eds.), African pastoralism, conflict, institutions and government. Amsterdam: Pluto Press, in association with Organization for Social Science Research in Eastern and Southern Africa, Amsterdam Research Institute for Global Issues and Development Studies.

FAO [Food and Agriculture Organisation]. 2012. Street food vending in West African cities: Potential and challenges. FAO Regional Office for Africa.

Fasoyiro, S. B. 2011. Assessment of hazards in local soy-cheese processing: implications on health and environment in Oyo State, Nigeria. WIT Transactions on Ecology and the Environment 152: 37-44. https://doi.org/10.2495/FENV110041

Graffham, A., Zulu, R. and Chibanda, D. 2005 Improving the safety of street vended foods in southern Africa. Final report, CPHP Project R8272. Online at http://www.ifpri.org/publications/results/taxonomy\%3A468

ILO [International Labour Office]. 2015a. World Employment and Social Outlook: Trends 2015. International Labour Office, Geneva.

ILO [International Labour Office]. 2015b. Five facts about informal economy in Africa. Online at: https://www.ilo.org/addisababa/whatsnew/WCMS_377286/lang--en/index.htm. (Accessed: 05 August 2018).

Kim, C. 1989. Working wives' time saving tendencies: Durable ownership, convenience food consumption and meal purchases. Journal of Economic 
Psychology 10: 391-409.

https://doi.org/10.1016/0167-4870(89)90031-7

Kooijman-van Dijk, A. L. 2008. The power to produce: The role of energy in poverty reduction through small scale enterprises in the Indian Himalayas. PhD dissertation, University of Twente, Enschede.

Maduka, J. O. 2006. Smoke gets in their eyes: The women fish smokers of Lagos. ENERGIA News 9: 12-13.

Meagher, K. 2010. The empowerment trap: gender, poverty and the informal economy in Sub-Saharan Africa. In Chant, S. (ed), The international handbook of gender and poverty: Concepts, research, policy. Edward Elgar: Gloucestershire, UK. https://doi.org/10.4337/9781849805162.00088

Matinga, M. N. 2015. LPG and livelihoods: Women in food processing in Accra. ENERGIA Newsletter 16 September 2015. 11-14

Mosupye, F. M. and von Holy, A. 1999. Microbiological quality and safety of ready-to-eat street-vended foods in Johannesburg, South Africa. Journal of Food Protection 62(11): 1278-1284. https://doi.org/10.4315/0362-028X-62.11.1278

Muzaffar, A. T., Huq, I. and Mallik, B. A. 2009. Entrepreneurs of the streets: An analytical work on the street food vendors of Dhaka City. International Journal of Business and Management 4(2): 80-88. https://doi.org/10.5539/ijbm.v4n2p80

Nickols, S., and Fox, K. 1983. Buying time and saving time: Strategies for managing household production. Journal of Consumer Research 10: 197-208. https://doi.org/10.1086/208959

Nirathron, N. 2006. Fighting poverty from the street: A survey of street food vendors in Bangkok. Bangkok. International Labour Office. Thailand Series, No. 1

NRI [Natural Resources Institute]. 2015. Street foods and informally vended food in Africa. Online at http://www.nri.org/project-websites/food-and-markets/street-foods-and-informally-vended-food-inafrica. (Accessed: 18 October 2017)

OECD [Organisation for Economic Co-operation and Development]. 2002. OECD handbook: Measuring the non-observed economy. OECD, Paris.

Onyeneho, S. N. and Hedberg, C. W. 2013. An assessment of food safety needs of restaurants in Owerri, Imo State, Nigeria. International Journal of Environmental Research and Public Health 10(8): 3296-3309. https://doi.org/10.3390/ijerph10083296

Osei-Boateng, C. and Amaratwum, E. 2011. The informal sector in Ghana. Friedrich Ebert Stiftung, Ghana.

Overå, R. 2007. When men do women's work: structural adjustment, unemployment and changing gender relations in the informal economy of Accra, Ghana. The Journal of Modern African Studies 45(4): 539563. https://doi.org/10.1017/S0022278X0700287X

Scott, E. P. 1995. Home-based industries: An alternative strategy for household security in rural Zimbabwe. Journal of Developing Areas 29(2): 183-212.

Sovacool, B. K., Clarke, S., Johnson, K., Crafton, M., Eidsness, J. and Zoppo, D. 2013. The energy-enter- prise-gender nexus: Lessons from the Multifunctional Platform (MFP) in Mali. Renewable Energy 50: 115125. https://doi.org/10.1016/j.renene.2012.06.024

Tedd, L., Liyanarachchi, S. and Ranjah Saha, S. 2003. Energy and street food. DFID KaR Project R7663. Rugby: Intermediate Technology Development Group.

Waters-Bayer, A. 1985. Dairying by settled Fulani women in Central Nigeria and some implications for dairy development. ODI Pastoral Development Network Paper 20c. London: Overseas Development Institute.

Winarno, F. G. and Allain, A. 1991. Street foods in developing countries: Lessons from Asia. Alimentation, Nutrition et Agriculture (FAO); Bangkok.

Winrock. 2005. Enabling urban poor livelihoods policy making: Understanding the role of energy services. Country report, Brazil. Salvador, Bahia: Prepared for DFID KaR Project R8348. 